\title{
FREE CASH FLOW, OUTSIDER OWNERSHIP, LEVERAGE, DAN KEBIJAKAN DIVIDEN TERHADAP KOS KEAGENAN
}

\author{
Gerianta Wirawan Yasa dan Ni Luh Ayu Sukrisna Dewi \\ Fakultas Ekonomi dan Bisnis Universitas Udayana \\ E-mail: geriwiya@yahoo.co.id
}

\begin{abstract}
The purpose of this study was to determine empirical evidence influence of free cash flow, leverage, institutional ownership, foreign ownership and dividend policy on agency cost. Agency relationships inflict agency conflicts that trigger agency cost. This research was conducted on all companies listed in Indonesia Stock Exchange in the year of observation 2012-2014Samples were selected by purposive sampling and acquired 38 companies. The analysis technique used is multiple linear regressions and there is additional sensitivity test to strengthentheresearch results, this research use different proxy agency cost such as selling and general administrative and asset turnover.Research results show that the free cash flow and institutional ownership has a positive influence on the agency cost, leverage negatively affect the agency cost, and foreign ownership and dividend policy does not affect the agency cost. While in sensitivity test is known that selling and general administrative proxies better able to explain agency cost compared with asset turnover.
\end{abstract}

Keywords: free cash flow, agency cost

\begin{abstract}
Abstrak: Penelitian inibertujuan untuk memeroleh bukti empiris pengaruh dari free cash flow, leverage, kepemilikan institusional, kepemilikan asing, dan kebijakan dividen terhadap kos keagenan.Hubungan keagenan menimbulkan konflik keagenan yang memicu timbulnya kos keagenan. Penelitian ini dilakukan pada seluruh perusahaan yang terdaftar di Bursa Efek Indonesia dalam tahun pengamatan 20122014. Sampel dipilih dengan teknik purposive sampling dan diperoleh 38 perusahaan. Teknik analisis yang digunakan adalah regresi linear berganda dan terdapat uji tambahan yaitu uji sensitivitas untuk memperkuat hasil penelitian dan digunakan proksi yang berbeda dalam kos keagenandiantaranya selling and general administrative dan asset turnover. Hasil penelitian menunjukkan bahwa free cash flow dan kepemilikan institusional berpengaruh positif terhadap kos keagenan, leverage berpengaruh negatif terhadap kos keagenan, dan kepemilikan asing serta kebijakan dividen tidak berpengaruh terhadap kos keagenan. Sedangkan dalam uji sensitivitas diketahui bahwa proksi selling and general administrativelebih mampu menjelaskan kos keagenan dibandingkan denganasset turnover.
\end{abstract}

Kata Kunci:free cash flow, kos keagenan.

\section{PENDAHULUAN}

Perusahaan yang terdaftar dalam Bursa Efek Indonesia (BEI) merupakan perusahaan go public yang menjual sahamnya kepada masyarakat luas. Sesuai dengan keputusan ketua Bapepam dan LK (Badan Pengawasan Pasar Modal dan Lembaga Keuangan) Nomor: 
Kep-346/BL/2011 mengenai pasar modal dijelaskan bahwa laporan keuangan tahunan wajib disampaikan oleh perusahaan go public kepada Bapepam dan LK serta diumumkan kepada masyarakat paling lambat pada akhir bulan ketiga setelah tanggal laporan keuangan tahunan. Para pemegang saham adalah pihak yang menerima langsung dampak yang diakibatkan oleh keputusan yang dibuat oleh manajemen.Ketika manajemen membuat suatu keputusan, manajemen tidak selalu mengutamakan kesejahteraan dari pemegang sahamnya melainkan pengambilan keputusan yang cenderung untuk meningkatkan utilitasnya sendiri.

Perusahaan-perusahaan besar seperti Enron, Tyco, WorldCom, London \& Commonwealth, dan perusahaan besar lainnya telah mengalami kebangkrutan yang diakibatkan oleh kegagalan strategi dan kecurangan oleh manajemen puncak yang telah berlangsung lama dikarenakan lemahnya pengawasan independen (Kaihatu, 2006). Pengabaian kepentingan para pemegang saham tentang pengembalian atas investasi yang telah dilakukannya menjadi permasalahan yang serius.

Teori keagenan menjelaskan fenomena tersebut yang dipopulerkan oleh Jensen dan Meckling (1976), yang menyatakan bahwa tujuan yang dimiliki oleh pemegang saham perusahaan (prinsipal) berbenturan dengan tujuan yang dimiliki oleh manajemen (agen). Hal ini akan menyebabkan terjadinya konflik kepentingan dan sering disebut sebagai konflik keagenan. Konflik keagenan juga disebabkan oleh asimetri informasi di antara pemegang saham dengan manajemen.

Hubungan keagenan memiliki masalah yang terdiri dari dua kategori yaitu adverse selectiondan moral hazard.Adverse selection terjadi ketika manajemen gagal memberikan kemampuannya dan cenderung mengambil keputusan yang merugikan, sedangkan moral hazard yaitu kondisi lingkungan di mana manajemen melalaikan tanggung jawab atau bertindak sesuai dengan kepentingannya sendiri dan bertentangan dengan kepentingan pemegang saham. Agar tidak terjadi kesulitan di masa depan yang berdampak buruk terhadap going concern perusahaan, prinsipal harus mengendalikan konflik keagenan ini.Konflik keagenan memicu timbulnya kos keagenan. Kos keagenan dikeluarkan untuk mengurangi kerugian yang mungkin timbul akibat ketidakpatuhan manajemen.Kos keagenanadalah kos yang timbul agar manajer bertindak selaras dengan tujuan pemilik (Nuswandari, 2009).Pemegang saham menginginkan agar kos keagenanini dapat diminimalisir.

Salah satu penyebab adanya konflik keagenan adalah ketika perusahaan menghasilkan free cash flow dalam jumlah yang besar. Free cash flow merupakan salah satu ukuran yang digunakan investor untuk mengukur kekuatan keuangan perusahaan. Jensen (1986) mengemukakan free cash flow adalah arus kas bersih yang setelah dikurangi dengan kebutuhan untuk mendanai proyek dengan Net Present Value (NPV) positif. Perusahaan akan mengalami masalah ketika tidak tersedianya proyek dengan NPV positif, oleh karena itu manajer dapat menyalahgunakan free cash flow tersebut seperti mengalokasikannya pada sumber daya yang tidak efisien dan perilaku konsumtif contohnya adalah pembelian mobil dinas mewah.

Penggunaan free cash flow yang efektif adalah ketika digunakan sesuai dengan kepentingan pemegang saham seperti berinvestasi dalam proyek dengan NPV positif dan/atau didistribusikan kepada pemegang saham dalam bentuk dividen (Crutchley dan Hansen, 1989). Free cash flow ini juga memiliki keterkaitan dengan bonding cost di mana manajemen menggunakannya sebagai mekanisme untuk membuktikan bahwa manajemen 
tidak akan menyalahgunakan dana perusahaan dan berani mengambil risiko kehilangan pekerjaan apabila tidak mengelola perusahaan dengan baik.

Terkait kasus perusahaan Enron yang melebih-lebihkan laba bersihnya dan menutupi semua utangnya sehingga menyebabkan kebangkrutan serta kerugian yang besar, maka perusahaan yang menyatakan menghasilkan laba harus didukung dengan informasi arus kas.Alasannya adalah apabila perusahaan menghasilkan laba yang besar tetapi arus kas yang rendah atau bahkan arus kas negatif dapat menimbulkan permasalahan yang serius.Begitupula sebaliknya, perusahaan yang menderita kerugian namun memiliki arus kas positif masih mampu bergerak dan dapat merencanakan kembali strateginya untuk menghasilkan laba di periode berikutnya.

Salah satu cara untuk mengatasi konflik keagenan dapat dilakukan dengan meningkatkan pendanaan melalui utang (leverage). Perusahaan memiliki kewajiban untuk mengembalikan pinjaman dan membayar beban bunga secara periodik. Penggunaan leverage dalam struktur modal dapat mencegah pengeluaran perusahaan yang tidak perlu dan memberikan dorongan pada manajer untuk mengoperasikan perusahaan dengan lebih efisien (Fachrudin, 2011). Manajemen juga harus menyediakan kas yang cukup untuk membayar utang serta bunganya, dan dari pemilik dana (debtholder) sendiri akan memonitoring perusahaan untuk mengetahui apakah dana yang diberikan telah dimanfaatkan dengan tepat.

Struktur kepemilikan adalah suatu mekanisme yang dapat digunakan untuk mengurangi konflik antara manajemen dan pemegang saham.Struktur kepemilikan merupakan bagian dari mekanisme internal corporate governance (Denis dan McConnell, 2003).Masalah keagenandapat dikurangi dengan adanya struktur kepemilikan (Faizal, 2004).Outsider ownership atau kepemilikan saham oleh pihak dari luar perusahaan diantaranya adalah kepemilikan saham oleh institusi dan kepemilikan saham oleh pihak asing. Kepemilikan institusional merupakan saham yang dimiliki oleh institusi keuangan, institusi pemerintah, institusi berbadan hukum, perusahaan investasi dan kepemilikan institusi lain. Struktur kepemilikan perusahaan publik di Indonesia terkonsentrasi pada institusi.Untuk kepemilikan asing, merupakan saham yang dimiliki oleh perorangan, badan hukum, pemerintah serta bagian-bagiannya yang berstatus luar negeri dan termasuk pula perusahaan multinasional.

Kepemilikan saham oleh institusi dan asing dapat menurunkan kos keagenan karena adanya monitoring untuk memengaruhi keputusan manajemen. Investor institusional memiliki dorongan untuk memonitor dan memengaruhi manajemen agar melindungi investasi mereka.Sedangkan dengan adanya kepemilikan asing dalam perusahaan, hal ini dianggap concern terhadap peningkatan good corporate governance (Simerly dan Li, 2000).Banyak perusahaan-perusahaan yang terdaftar di BEI yang memiliki kepemilikan asing dalam daftar shareholder-nya, ini artinya bahwa di Indonesia telah mengalami peningkatan good corporate governance dari semenjak krisis moneter tahun 1998.Salah satu contoh perusahaan yang memiliki kepemilikan institusi dan asing adalah PT Bank Danamon Indonesia Tbk. yang menjadikan perusahaan tersebut masuk dalam sepuluh besar dengan GCG terbaik di Indonesia tahun 2013 (bisnis.tempo.co).

Kos keagenan juga dapat dikurangi dengan kebijakan membagikan sejumlah laba yang diperoleh perusahaan dalam bentuk dividen.Kebijakan dividen ditentukan dalam Rapat Umum Pemegang Saham (RUPS) sehingga besar kecilnya dividen yang dibayarkan per lembar saham sangat dipengaruhi oleh keinginan pemegang saham serta kondisi keuangan 
di perusahaan.Kelebihan kas yang ada di perusahaan sebaiknya dibagikan dalam bentuk dividen (Karen, 2003), namun manajemen lebih memilih untuk menjadikannya sebagai laba ditahan yang akan digunakan untuk mendanai proyek atau ekspansi agar perusahaan dapat terus tumbuh dan berkembang. Peran dari dividen itu sendiri adalah bentuk penawaran distribusi pendapatan karena ketika perusahaan membayar dividen, pemegang saham meyakini bahwa perusahaan telah dikelola dengan baik oleh manajemen dan sesuai dengan keinginannya sehingga dengan membayar dividen dapat mengurangi konflik keagenan.

Beberapa penelitian terdahulu telah meneliti hubungan kos keagenan yang ditimbulkan oleh konflik keagenan. Namun, penelitian-penelitian ini memberikan hasil yang tidak konsisten, yang mungkin disebabkan oleh faktor-faktor lain yang tidak dijelaskan dalam teori. Seperti penelitian yang dilakukan oleh Wang (2010) yang melakukan pengujian mengenai pengaruh free cash flow terhadap kos keagenan pada perusahaan yang terdaftar di Bursa Efek Taiwan. Hasil penelitian Wang menunjukkan bahwa free cash flow yang dihasilkan dari efisiensi manajemen operasi dapat menurunkan kos keagenan. Namun, free cash flow jugadapat meningkatkan kos keagenan karena berpengaruh menurunkan asset turnover sehingga menyebabkan peningkatan kos keagenan. Hasil ini konsisten dengan temuan dari Jensen dan Meckling (1976), Brush et al.,(2000) dan Fosberg et al., (2003) bahwa free cash flow dapat meningkatkan kos keagenan.

Selain mengenai pengaruh free cash flow terhadap kos keagenan, beberapa studi empiris juga meneliti mengenai hubungan struktur kepemilikan terhadap kos keagenan, diantaranya Ang et al., (2000) meneliti tentang kos keagenan dan struktur kepemilikan di 1708 perusahaan kecil yang diambil dari FRB/NSSBF database. Hasil yang diperoleh adalah kos keagenan akan semakin tinggi ketika outsider memiliki saham perusahaan.

Berbeda denganGul et al., (2012)yang meneliti mengenai agency cost, corporate governance, and ownership structure pada perusahaan yang terdaftar di Karachi Stock Exchange tahun 2003-2006, memeroleh hasil struktur kepemilikan manajerial, kepemilikan institusional, kepemilikan eksternal dan tata kelola perusahaan dapat menurunkan kos keagenan. Hasil yang sama diperoleh oleh Rahmadiyani (2012) yang meneliti tentang pengaruh struktur kepemilikan terhadap kos keagenan dengan aktivitas pengawasan dewan komisaris sebagai pemoderasi pada perusahaan manufaktur periode 2008-2010, menyimpulkan bahwa struktur kepemilikan keluarga, struktur kepemilikan institusi, dan struktur kepemilikan asing yang dimoderasi oleh pengawasan dewan komisaris berpengaruh negatif terhadap kos keagenan.

Selanjutnya oleh Hadiprajitno (2013) mengenai struktur kepemilikan dan mekanisme corporate governance terhadap kos keagenan pada perusahaan yang terdaftar di BEI tahun 2008-2009 yang menghasilkan temuan bahwa struktur kepemilikan keluarga, struktur kepemilikan institusi, dan struktur kepemilikan pemerintah berpengaruh negatif terhadap kos keagenan dan struktur kepemilikan asing berpengaruh positif terhadap kos keagenan. Purnami (2011) meneliti mengenai pengaruh kepemilikan manajerial, kepemilikan institusional, kebijakan dividen, dan leverage pada kos keagenan menemukan bahwa kepemilikan manajerial berpengaruh negatif, namun kepemilikan institusional, kebijakan dividen, dan leverage tidak memiliki pengaruh terhadap kos keagenan. Sedangkan penelitian yang dilakukan oleh Widanaputra dan Ratnadi (2008) yang meneliti pengaruh kebijakan dividen,leverage, dan kepemilikan manajerial terhadap kos keagenan 
menyimpulkan bahwa leverage berpengaruh negatif, kepemilikan manajerial dapat mengurangi kos keagenan sedangkan kebijakan dividen tidak berpengaruh terhadap kos keagenan. Namun, Schooley et al., (1994) mengungkapkan bahwa kebijakan dividen dan kepemilikan manajerial digunakan untuk menurunkan kos keagenan. Schooley et al., (1994) menguji kebijakan dividen dan kepemilikan saham sebagai suatu hal yang dapat mengurangi kos keagenan.

Penelitian ini meneliti seluruh perusahaan yang telah terdaftar di Bursa Efek Indonesia karena seluruh perusahaan publik memiliki kos keagenan.Adanya hasil yang berbeda dalam penelitian sebelumnya (research gap) maka diperlukan penelitian lebih lanjut dari variabel-variabel tersebut dan membuktikannya secara empiris.Dengan demikian yang menjadi pokok permasalahan dalam penelitian ini adalah: (1) apakah free cash flow berpengaruh positif terhadap kos keagenan?; (2) apakah leverageberpengaruh negatif terhadap kos keagenan?;(3) apakah kepemilikan institusionalberpengaruh negatif terhadap kos keagenan?;(4) apakah kepemilikan asingberpengaruh negatif terhadap kos keagenan?; dan (5) apakah kebijakan dividen berpengaruh negatif terhadap kos keagenan?

\section{KAJIAN TEORI}

Teori Keagenan. Teori keagenan disebut teori kontraktual yang memandang suatu perusahaan sebagai suatu perikatan kontrak antara anggota-anggota perusahaan (Jensen dan Meckling, 1986).Manajemen adalah pihak yang dikontrak oleh pemegang saham untuk bekerja atas dasar kepentingan pemegang saham.Oleh karena itu manajemen dilimpahkansebagian kekuasaan untuk mengambil keputusan bagi kepentingan pemegang saham (diskresi manajerial), sehingga manajemen memiliki kewajiban untuk mempertanggungjawabkan semua kinerjanya kepada pemegang saham.

Messier et al.,(2006) menyatakan bahwa hubungan keagenan ini menimbulkan dua permasalahan, yaitu asimetri informasi dan konflik kepentingan.Asimetri informasi terjadi ketika manajemen mengetahui lebih banyak informasi serta keadaan di dalam perusahaan jika dibandingkan dengan pemegang saham.Sedangkan konflik keagenan disebabkan oleh tindakan manajemen yang tidak selalu mementingkan kesejahteraan pemegang saham dan kedua belah pihak memiliki tujuan yang berbeda.

Kos Keagenan. Jensen dan Meckling (1976) menyatakan bahwa terdapat tiga jenis kos keagenan.(1) biaya pengawasan (monitoring cost), biaya ini untuk mengawasi aktivitas dan perilaku manajer antara lain membayar auditor untuk mengaudit laporan keuangan perusahaan dan premi asuransi untuk melindungi asetperusahaan, pembatasan anggaran, biaya untuk menetapkan rencana kompensasi manajer, dan aturan-aturan operasi; (2) biaya ikatan (bonding cost), biaya yang ditanggung oleh manajemen untuk menetapkan dan mematuhi mekanisme yang menjamin bahwa manajemen bertindak untuk kepentingan pemegang saham. Contohnya biaya untuk menyediakan laporan keuangan kepada pemegang saham, dan kelancaran dalam membayar bunga bank (Purnami,2011); (3) Residual Loss, biaya ini juga dikeluarkan oleh manajemen yang diakibatkan oleh pengambilan keputusan yang salah dan lolos dari pengawasan. Biaya ini didefinisikan sebagai kerugian atau penurunan tingkat kesejahteraan pemegang saham maupun manajemen setelah terjadinya hubungan keagenan. 
Struktur Kepemilikan (Ownership Structure). Struktur kepemilikan saham mencerminkan distribusi kekuasaan dan pengaruh diantara pemegang saham atas kegiatan operasional perusahaan.Salah satu karakteristik struktur kepemilikan adalah struktur kepemilikan insider ownership dan outsider ownership.Insider ownership adalah saham yang dimiliki oleh pemilik perusahaan dan merupakan pengelola perusahaan yang bisa juga disebut dengan kepemilikan saham manajerial.Sedangkan outsider ownership adalah kepemilikan saham oleh pihak dari luar perusahaan, dalam penelitian ini diproksikan dengan kepemilikan saham oleh institusi dan kepemilikan saham oleh pihak asing.

Struktur kepemilikan saham oleh pihak luar (outsider ownership) biasanya mempunyai persentase kepemilikan lebih dari 50 persen sehingga mampu memengaruhi kondisi dan hasil kinerja serta memonitoring secara efektif.Adanya monitoring dari outsider ownership ini maka pihak manajemen dituntut harus mampu menunjukkan kinerja yang baik.Upaya manajemen untuk menunjukkan hasil kinerja yang optimal adalah dengan menyediakan informasi mengenai keuangan dan kinerja perusahaan. Outsider ownership memiliki kekuatan yang besar untuk menekan manajemen dalam menyajikan informasi secara tepat waktu, karena ketepatan waktu pelaporan akan memengaruhi pengambilan keputusan yang tepat.

Kepemilikan institusional adalah kepemilikan saham perusahaan yang dimiliki oleh institusi atau lembaga seperti perusahaan asuransi, bank, perusahaan investasi dan kepemilikan institusi lain (Tarjo, 2008). Mayoritas bentuk institusi adalah Perseroan Terbatas (PT).Perusahaan yang memiliki investor institusional mencerminkan bahwa perusahaan tersebut memiliki monitoring external sehingga dapat memonitor tindakan manajemen.

Institutional shareholders dengan kepemilikan saham yang besar memiliki insentif untuk memantau pengambilan keputusan perusahaan (Barnae dan Rubin, 2005). Semakin besar kepemilikan institusi akan berdampak semakin besar pula kekuatan suara (votting) dan dorongan untuk memonitoring manajemen sehingga akan dapat mengoptimalkan nilai perusahaan. Curthleyet al.,(1999) menemukan bahwa monitoring yang dilakukan institusi mampu mensubstitusi kos keagenan, sehingga kos keagenan dapat diminimalisir. Gedajlovic dan Shapiro (2002) berpendapat bahwa kepemilikan saham oleh institusi akan mampu memberikan pengendalian yang efektif bagi manajemen karena padatnya jaringan bisnis, utang, dan modal perusahaan.

Kepemilikan asing adalah kepemilikan saham biasa (common stock) perusahaan yang yang dimiliki oleh perorangan, badan hukum, pemerintah, serta bagian-bagiannya yang berstatus luar negeri (Aryani, 2011).Menurut Anggraini (2011) kepemilikan asing merupakan kepemilikan saham yang dimiliki oleh perusahaan multinasional.Biasanya perusahaan yang sahamnya sebagian besar dimiliki oleh investor asing cenderung menghadapi masalah asimetri informasi yang disebabkan oleh hambatan geografis, budaya, dan bahasa. Investor asing menghadapi risiko yang cukup besar dalam berinvestasi di negara yang masih berkembang, termasuk risiko politik, risk bearing dan hukum di negara tersebut. La Porta, et al., (1999) mengungkapkan bahwa karena investor asing menghadapi risiko yang besar maka monitoring yang dilakukan oleh investor asing relatif lebih tinggi sehingga dapat memberikan tekanan terhadap perusahaan agar lebih efisien memanfaatkan sumber daya sehingga mampu mengurangi kos keagenan.

Investor asing cenderung lebih pintar dan memiliki berbagai inovasi, sehingga perusahaan dengan kepemilikan asing akan memiliki pengetahuan lebih baik yang 
berdampak pada peningkatan nilai perusahaan. Menurut Almilia (2008), perusahaan yang memiliki investor asing dalam daftar shareholder-nya cenderung melakukan pengungkapan yang lebih luas, karena perusahaan tersebut memiliki teknologi yang cukup untuk menciptakan sistem informasi manajemen yang lebih efisien sehingga lebih mudah memberi akses dalam sistem pengendalian intern. Perusahaan dengan kepemilikan asing juga akan memberikan pelatihan bagi tenaga kerjanya terkait dengan pekerjaan yang dilakukan dan berdampak pada efisiensi produktivitas perusahaan.

Free Cash Flow. Free cash flow memberikan implikasi penting dalam konflik keagenan (Jensen, 1986). Manajemen bisa saja melakukan investasi dengan NPV negatif atau poor investment decision. Hal ini disebabkan karena ketika sebuah perusahaan dengan free cash flow yang besar dan tidak tersedia proyek yang menguntungkan, manajemen akan cenderung menyalahgunakan free cash flow dengan perilaku oportunistik. Contoh dari perilaku oportunistik adalah mengalokasikan sumber daya yang tidak efisien, perilaku konsumtif yang berlebihan, dan berinvestasi dengan NPV negatif sehingga akan membebankan pemegang saham (Piramita, 2012).

Penggunaan free cash flow yang efisien adalah ketika perusahaan telah mendanai semua proyek dengan NPV positif dan kelebihan arus kas ini bisa didistribusikan kepada pemegang saham dengan pembelian kembali saham (treasury stock) dan pembayaran dividen (Crutchley dan Hansen, 1989). Dengan kata lain ketika kepentingan pemegang saham dan manajemen secara sempurna telah sejalan maka manajemen akan mendistribusikan semua free cash flow kepada pemegang saham (Mann dan Sicherman, 1991).

Leverage. Brigham dan Houston (2011:140) mengemukakan bahwa rasioleverage merupakan rasio yang mengukur sejauh mana perusahaa menggunakan pendanaan melalui utang (financial leverage). Perusahaan dinilai berisiko apabila memiliki porsi leverage yang besar dalam struktur modal, namun apabila perusahaan menggunakan leverage yang kecil atau tidak ada leverage maka perusahaan dinilai tidak dapat memanfaatkan tambahan modal eksternal yang dapat meningkatkan operasional perusahaan (Ozkan, 2001).

Pendanaan melalui leverage dapat memberikan dampak dalam konflik dan kos keagenan. Dengan leverage, manajer akan mengoptimalkan penggunaan dana yang ada. Perusahaan yang memiliki jumlah leverage yang besar akan menimbulkan kesulitan keuangan serta risiko kebangkrutan. Leveragedapat memberikan sinyal mengenai status kondisi keuangan perusahaan untuk memenuhi kewajibannya.

Rasio leverage yang besar dapat memengaruhi manajer dan menurunkan kos keagenan melalui ancaman likuiditas yang berdampak pada gaji personal dan reputasi manajemen (Yegon et al., 2014).Menurut Jurkus et al., (2011) melalui peningkatan utang atau leverage akan dapat meningkatkan monitoring eksternal oleh debtholder. Perusahaan dengan tingkat leverage rendah akan menanggung kos keagenan yang lebih tinggi dibandingkan dengan perusahaan yang memiliki tingkat utang yang tinggi, sehingga antara leverage dengan kos keagenan memiliki hubungan terbalik (Byrd, 2010).

Kebijakan Dividen. Kebijakan dividen adalah keputusan apakah laba yang diperoleh perusahaan akan dibagikan kepada pemegang saham sebagai dividen atau akan ditahan dalam bentuk laba ditahan (retairned earnings) guna pembiayaan investasi dimasa mendatang. Dividen diartikan sebagai pembayaran kepada pemegang saham oleh 
perusahaan atas laba yang dihasilkan.Kebijakan dividen merupakan keputusan yang sangat penting dalam perusahaan. Kebijakan ini akan melibatkan dua pihak yang mempunyai kepentingan yang berbeda, yaitu pihak pertama para pemegang saham dan pihak kedua adalah manajemen.

Kebijakan dividen menimbulkan kontroversi karena apabila pembayaran dividen ditingkatkan maka arus kas untuk pemegang saham akan meningkat dan menguntungkan pemegang saham, sedangkan alasan lainnya yaitu apabila pembayaran dividen ditingkatkan maka laba ditahan yang direinvestasi dan pertumbuhan masa depan akan menurun sehingga merugikan pemegang saham. Oleh karena itu, kebijakan dividen dikatakan optimal apabila mampu menyeimbangkan kedua hal tersebut. Pembayaran dividen dalam jumlah sekecil apapun masih lebih baik daripada tidak sama sekali. Menurut Crutchley dan Hansen (1989), peningkatan dividen diharapkan dapat mengurangi kos keagenan.

Hipotesis Penelitian. Dari uraian yang telah dijelaskan dapat dirumuskan hipotesis sebagai berikut.

$\mathrm{H}_{1}$ : Free cash flow berpengaruh positif terhadap kos keagenan.

$\mathrm{H}_{2}$ : Leverage berpengaruh negatif terhadap kos keagenan.

$\mathrm{H}_{3}$ : Kepemilikan institusionalberpengaruh negatif terhadap kos keagenan.

$\mathrm{H}_{4}$ : Kepemilikan asingberpengaruh negatif terhadap kos keagenan.

$\mathrm{H}_{5}$ : Kebijakan dividenberpengaruh negatif terhadap kos keagenan.

\section{METODE}

Populasi dalam penelitian ini adalah seluruh perusahaan yang terdaftar di Bursa Efek Indonesia tahun pengamatan 2012-2014. Metode yang digunakan dalam penentuan sampel adalah purposive sampling dengan beberapa kriteria sebagai berikut: (1)perusahaan yang terdaftar di BEI dan laporan keuangan auditannya disajikan dalam mata uang rupiah tahun 2012-2014; (2) perusahaan yang memiliki kelengkapan mengenai proporsi saham. (3) perusahaan yang memeroleh laba dan membagikan dividen dalam tahun pengamatan meskipun tidak berturut-turut. Diperoleh 38 perusahaan sampel dengan 114 pengamatan.

Definisi operasional masing-masing variabel dijelaskan sebagai berikut. Kos keagenan diproksikan dengan selling and general administrative (SGA) yaitu rasio antara beban operasional dengan total penjualan.SGA menunjukkan diskresi manajemen dalam memanfaatkan sumber daya perusahaan, semakin tinggi beban diskresi manajerial maka semakin tinggi kos keagenan dalam perusahaan(Widanaputra dan Ratnadi, 2008).

Free cash flow diukur dengan selisih dari operating cash flow dengan net capital expenditure (Brealey et al, 2008:158), kemudian dibagi dengan total aset agar lebih komparabel dengan perusahaan sampel dan relatif dengan ukuran perusahaan. Leverage diproksi dengan debttototal asset ratio(DAR).DAR adalah sebuah rasio untuk mengukur jumlah aset yang dibiayai oleh utang.Rasio ini juga sangat penting untuk melihat solvabilitas perusahaan. Kepemilikan institusional dan kepemilikan asing diperoleh dari persentase jumlah saham yang dimiliki oleh pihak institusi dan pihak asing berdasarkan jumlah saham yang beredar. Kebijakan dividen diproksi dengan dividend payout ratio yang dihitung dengan membandingkan dividen per lembar saham atau dividend per share (DPS) dengan laba per lembar saham atau earning per share (EPS). 
Teknikanalisisdatayang digunakan untuk menguji hipotesis adalahregresi linear berganda yang diformulasikan sebagai berikut.

AC_SGA $\quad=\alpha+\beta_{1} \mathrm{FCF}+\beta_{2} \mathrm{DAR}+\beta_{3} \mathrm{~K}$.inst $+\beta_{4} \mathrm{~K}$.asing $+\beta_{5} \mathrm{DPR}+\varepsilon$

Keterangan: AC_SGA = agency cost yang diproksi selling and general administrative; $\mathrm{FCF}=$ free cash flow; DAR $=$ debt to total assets ratio; $\mathrm{K} . \mathrm{inst}=$ persentase saham yang dimiliki oleh institusi; K.asing = persentase saham yang dimiliki oleh pihak asing; DPR = dividend payout ratio; $\varepsilon=$ error

Terlebih dahulu dilakukan uji statistik deskriptif, statistik deskriptif adalah statistik yang digunakan untuk menganalisa data dengan cara mendeskripsikan atau menggambarkan data yang telah terkumpul sebagaimana adanya tanpa bermaksud membuat kesimpulan yang berlaku untuk umum atau generalisasi (Sugiyono, 2013:206). Kemudian dilakukan uji asumsi klasik karena dalam uji hipotesis harus menghindari adanya kemungkinan terjadinya penyimpangan asumsi-asumsi klasik. Pengujian yang dilakukan diantaranya uji normalitas untuk mengetahui apakah sampel yang digunakan dalam penelitian ini berdistribusi normal atau tidak dengan melihat nilai probabilitasnya yang lebih besar dari taraf signifikansi 0,05, uji multikolinearitas untuk menguji apakah pada model regresi ditemukan adanya korelasi antar variabel independen yaitu dengan melihat besaran nilai VIF (Variance Inflation Factor) di sekitar angka satu dan angkaTolerancemendekati satu, uji heteroskedastisitasuntuk menguji apakah dalam model regresi terjadi ketidaksamaan varians dari residual suatu pengamatan ke pengamatan lainnya dengan menggunakan metode Glejser, dan terakhir uji autokorelasi untuk menguji apakah terdapat autokorelasi atau pengaruh data penelitian sebelumnya dalam suatu model regresi dengan menggunakan uji Durbin-Watson.

Koefisien determinasi $\left(\mathrm{R}^{2}\right)$ digunakan untuk mengukur seberapa jauh kemampuan model regresi dalam menjelaskan variasi dari variabel dependen dengan melihat nilaiadjusted $\mathrm{R}^{2}$. Selanjutnya, uji kelayakan model digunakan dengan uji $\mathrm{F}$. Manfaat dari uji $\mathrm{F}$ ini adalah untuk mengetahui model regresi yang dibuat sudah tepat atau tidak. Sedangkan untuk uji hipotesis digunakan uji t dengan melihat signifikansi t atau p value $\leq$ 0,05 maka hipotesis diterima.

Penelitian ini menggunakan uji tambahan yaitu uji sensitivitas karena terdapat lebih dari satu proksi yang dapat digunakan dalam menghitung suatu variabel (Yasa, 2010).Uji sensitivitas dimaksudkan untuk menguji apakah kos keagenan tetap dipengaruhi oleh free cash flow, leverage, kepemilikan institusional, kepemilikan asing, dan kebijakan dividen jika proksi kos keagenan yang digunakan berbeda. Untuk menguji hal tersebut dilakukan dengan proksiasset turnoverdan proksi ini tidak menjawab hipotesis.Asset turnover merupakan rasio antara penjualan dibagi dengan total aset yang menunjukkan asset utilization, yaitu mengukur kemampuan manajemen dalam menggunakan asetnya secara efisien pada investasi yang produktif.Untuk memperkuat hasil penelitian maka digunakan uji sensitivitas, dengan adanya uji sensitivitas, maka penelitian ini melibatkan model regresi berikut ini.

AC_AT $\quad=\alpha+\beta_{1} \mathrm{FCF}+\beta_{2} \mathrm{DAR}+\beta_{3} \mathrm{~K}$.inst $+\beta_{4} \mathrm{~K}$.asing $+\beta_{5} \mathrm{DPR}+\varepsilon$

Keterangan: AC_AT $=$ agency cost yang diproksi asset turnover $; \mathrm{FCF}=$ free cash flow; $\mathrm{DAR}=$ debt to total assets ratio; K.inst = persentase saham yang dimiliki oleh institusi; $\mathrm{K}$.asing = persentase saham yang dimiliki oleh pihak asing; DPR = dividend payout ratio $\varepsilon=$ error 


\section{HASIL DAN PEMBAHASAN}

Berikut adalah hasil dari teknik analisis data, yang pertama adalah hasil analisis statistik deskriptif mengenai deskripsi variabel melalui nilai rata-rata (mean), nilai minimum, nilai maksimum, dan deviasi standar dapat dilihat pada Tabel 1.

Tabel 1. Statistik Deskriptif Variabel Penelitian

\begin{tabular}{lrrrrr}
\hline Variabel & $\mathrm{N}$ & Minimum & Maksimum & Rata-rata & Deviasi Standar \\
FCF & 114 & $-0,1662$ & 0,4045 & 0,0488 & 0,0938 \\
DAR & 114 & 0,1300 & 0,7100 & 0,4474 & 0,1413 \\
K.Ins & 114 & 0,0522 & 0,8190 & 0,2811 & 0,1739 \\
K.Asing & 114 & 0,0132 & 0,7942 & 0,2688 & 0,1808 \\
DPR & 114 & 0,0000 & 4,7029 & 0,3120 & 0,5114 \\
SGA & 114 & 0,0284 & 0,3439 & 0,1431 & 0,0750 \\
\hline
\end{tabular}

Hasil dari analisis statistik deskriptif menunjukkan nilai rata-rata FCF (free cash flow) adalah sebesar 0,0488. Nilai rata-rata tersebut mencerminkan bahwa secara umum perusahaan-perusahaan yang terdaftar di BEI dan yang menjadi sampel dalam penelitian ini memiliki FCFpositif menunjukkan bahwa terdapat dana berlebih pada perusahaan yang dapat digunakan untuk berinvestasi atau dibagikan kepada para pemegang saham. Untuk hasil analisis statistik deskriptif variabel DARmenunjukkan nilai rata-rata 0,4474yang artinyasecara umum perusahaan sampel memiliki leverage sebesar 44,74 persen dari total aset.

Hasil analisis statistik deskriptif menunjukkan nilai rata-rata kepemilikan institusional adalah 0,2811. Rata-rata yang hanya sebesar 28,11 persen artinya bahwa masih rendahnya kepemilikan institusional yang dimiliki oleh perusahaan sampel. Untuk nilai rata-rata kepemilikan asing sebesar 0,2688, yang artinya secara umum perusahaan sampel memiliki investor asing yang rendah yaitu hanya 26,88. Hasil analisis statistik deskriptif menunjukkan rata-rata nilai DPR adalah 0,3120. Rata-rata sebesar 31,20 persen terbilang masih rendah dan mengindikasikan bahwa rata-rata perusahaan sampel masih bertumbuh. Untuk hasil analisis statistik deskriptif dari SGA menunjukkan nilai rata-rata sebesar 0,1431. Rata-rata sebesar 14,31 persen artinya perusahaan yang menjadi sampel memiliki SGA yang kecil. Semakin kecil rasio SGA maka kos keagenan juga semakin rendah.

Selanjutnya adalah hasil dari uji asumsi klasik dapat dilihat pada Tabel 2. Modelregresi yang baik seharusnya memiliki distribusi data yangnormal, tidak ada autokorelasi, tidak ada korelasiantar variablebebas dan tidak mengandung gejala heteroskedastisitas.

Tabel 2. Hasil Uji Normalitas

\begin{tabular}{lc}
\hline \multicolumn{1}{c}{ Kolmogorov-Smirnov $Z$} & Unstandardized Residual \\
\hline $\mathrm{N}$ & 114 \\
Asymp. Sig & 0,348 \\
\hline
\end{tabular}


Hasil menunjukkan nilai Asymp. Sig $(0,348)$ di mana nilai ini lebih besar dari 0,05. Dengan demikian, model yang dibuat sudah terdistribusi normal.

Tabel 3. Hasil Uji Heteroskedastisitas

\begin{tabular}{lcc}
\hline \multicolumn{1}{c}{ Variabel } & Sig. & Keterangan \\
\hline FCF & 0,842 & Bebas heteroskedastisitas \\
DAR & 0,096 & Bebas heteroskedastisitas \\
K.Ins & 0,449 & Bebas heteroskedastisitas \\
K.Asing & 0,254 & Bebas heteroskedastisitas \\
DPR & 0,331 & Bebas heteroskedastisitas \\
\hline
\end{tabular}

Berdasarkan Tabel 3 terlihat bahwa nilai sig. pada masing-masing variabel berada di atas 0,05. Dengan demikian, model yang dibuat tidak mengandung gejala heteroskedastisitas.

Tabel 4. Hasil Uji Multikolinearitas

\begin{tabular}{lcc}
\hline \multicolumn{1}{c}{ Variabel } & Tolerance & VIF \\
\hline FCF & 0,874 & 1,145 \\
DAR & 0,889 & 1,124 \\
K. Ins & 0,665 & 1,505 \\
K. Asing & 0,723 & 1,383 \\
DPR & 0,849 & 1,177 \\
\hline
\end{tabular}

Berdasarkan Tabel 4 diketahui bahwa nilai tolerance semua variabel independen lebih besar dari 0,10 dan nilai VIF semua variabel independen lebih kecil dari 10,00. Dengan demikian, dapat disimpulkan bahwa tidak terdapat gejala multikolinearitas.

Tabel 5. Hasil Uji Autokorelasi

\begin{tabular}{cccccc}
\hline Model & $\mathrm{R}$ & $R$ Square & $\begin{array}{c}\text { Adjusted } R \\
\text { Square }\end{array}$ & $\begin{array}{c}\text { Std. Error of } \\
\text { the Estimate }\end{array}$ & Durbin-Watson \\
\hline 1 & 0,519 & 0,269 & 0,235 & 0,6560 & 2,186 \\
\hline
\end{tabular}

Hasil uji autokorelasi pada Tabel 5 dengan level of significant sebesar 5 persen, $\mathrm{n}=$ 114 , dan jumlah variabel independen (k') sebanyak 5, maka diperoleh nilai $\mathrm{d}_{\mathrm{L}}=1,6042$ dan $\mathrm{d}_{\mathrm{U}}=1,7874$. Oleh karena nilai Durbin-Watson sebesar 2,186 di mana nilai tersebut lebih besar dari batas atas $\left(\mathrm{d}_{\mathrm{U}}\right)$ yakni 1,7874 dan kurang dari 2,2126 (4- $\left.\mathrm{d}_{\mathrm{U}}\right)$, makadapat disimpulkan bahwa tidak ada autokorelasi atau model regresi yang dibuat tidak mengandung gejala autokorelasi,sehingga layak digunakan untuk memprediksi.

Uji analisis regresi linear berganda dilakukan terhadap free cash flow, leverage, kepemilikan institusional, kepemilikan asing, dan kebijakan dividen terhadap kos keagenan. Berdasarkan perhitungan dengan bantuan program IBM SPSS versi 22, maka hasil analisis regresi linear berganda disajikan pada tabel berikut. 
Tabel 6. Hasil Analisis Regresi Linear Berganda

\begin{tabular}{lrrrrr}
\hline \multirow{2}{*}{ Model } & \multicolumn{2}{c}{$\begin{array}{c}\text { Unstandardized } \\
\text { Coefficients }\end{array}$} & $\begin{array}{c}\text { Standardized } \\
\text { Coefficients }\end{array}$ & \multirow{2}{*}{$\mathrm{t}$} & \multirow{2}{*}{ Sig. } \\
\cline { 2 - 4 } & \multicolumn{1}{c}{$\mathrm{B}$} & \multicolumn{1}{c}{ Std. Error } & \multicolumn{1}{c}{ Beta } & & \\
\hline (Constant) & 0,168 & 0,025 & & 6,697 & 0,000 \\
FCF & 0,140 & 0,070 & 0,175 & 1,988 & $0,049^{*}$ \\
DAR & $-0,188$ & 0,046 & $-0,354$ & $-4,060$ & $0,000^{*}$ \\
K.Ins & 0,191 & 0,044 & 0,443 & 4,394 & $0,000^{*}$ \\
K.Asing & 0,004 & 0,040 & 0,009 & 0,096 & 0,924 \\
DPR & $-0,008$ & 0,013 & $-0,058$ & $-0,648$ & 0,519 \\
Fhitung $_{\text {Sig. Fhitung }}$ & & & 7,954 & & \\
$\mathrm{R}^{2}$ & & & 0,000 & & \\
Adjusted $\mathrm{R}^{2}$ & & & 0,269 & & \\
\hline Keterangan & & & 0,235 & & \\
\hline
\end{tabular}

Keterangan $*$ ): signifikan pada tingkat $\alpha=0,05$

Tabel 6 menunjukkan koefisien masing-masing variabel dan diperoleh persamaan regresi sebagai berikut.

AC_SGA $=0,168+0,140 \mathrm{FCF}-0,188 \mathrm{DAR}+0,191 \mathrm{~K} . \mathrm{Ins}+$ 0,004K.Asing - 0,008DPR + E..(1)

Hasil pengolahan data pada Tabel 6 menunjukkan bahwa model regresi memiliki nilai adjusted $\mathrm{R}^{2}$ sebesar 0,235. Hal ini berarti bahwa sebesar 23,5 persen variabel independen yaitu free cash flow, leverage, kepemilikan institusional, kepemilikan asing, dan kebijakan dividen dapat menjelaskan varians dari variabel dependen kos keagenan. Sedangkan sisanya sebesar 76,5 persen dijelaskan oleh faktor lain di luar penelitian. Dan hasil dari olahan data menunjukkan nilai $F_{\text {hitung }}$ sebesar 7,954 dengan signifikansi 0,000. Hal ini berarti bahwa model regresi yang dibuat sudah layak.

Hasil dari uji t pada Tabel 6 menunjukkanpengujian hipotesis $\mathrm{H}_{1}$ diperoleh bahwa free cash flow berpengaruh positif terhadap kos keagenan. Hal ini menunjukkan bahwa dengan adanya peningkatan free cash flow akan menyebabkan kos keagenan juga meningkat. Free cash flow dalam jumlah yang besar akan memungkinkan manajemen untuk menyalahgunakan free cash flow tersebut seperti melakukan investasi yang tidak efisien dan menggunakannya untuk pengeluaran yang tidak semestinya. Hasil penelitian ini konsisten dengan penelitian Jensen (1986), Fosberg et al.,(2003), Richardson (2006), dan Chu (2011) yang menyimpulkan bahwa free cash flow memiliki hubungan positif dengan kos keagenan. Keberadaan free cash flow yang besar akan meningkatkan kos keagenan dikarenakan perilaku self-interest motive manajemen yang menyebabkan penurunan kesejahteraan pemegang saham.

Hasil pengujian hipotesis kedua $\left(\mathrm{H}_{2}\right)$ diperoleh bahwa leverage berpengaruh negatif terhadap kos keagenan. Hal ini ditunjukkan dengan signifikansi sebesar 0,000 di mana nilai ini lebih kecil dari tingkat signifikansi 0,05 . Hasil penelitian ini terbukti menerima hipotesis kedua $\left(\mathrm{H}_{2}\right)$ dan konsisten dengan penelitian dari Widanaputra dan Ratnadi (2008). Semakin meningkatnya leverage dalam struktur modal perusahaan, maka kos keagenan dapat diminimalisir. Afridian dan Yossi (2008) menyatakan bahwa dengan meningkatkan pendanaan melalui utang dapat mengurangi konflik keagenan. Penurunan 
kos keagenan disebabkan oleh pengawasan terhadap manajemen semakin berkurang karena si pemilik dana (debtholder)seperti bank dan lembaga keuangan lainnya, serta badan pemeringkat obligasi mampu memonitoring kinerja manajemen dengan baik atas dana yang dipinjamkan dan debtholder sendiri memiliki hak untuk membawa perusahaan ke jalur hukum apabila perusahaan tidak memenuhi perjanjian utang terutama dalam membayar bunga dan pokok pinjamannya (Khan et al,, 2012).

Hasil pengujian hipotesis ketiga $\left(\mathrm{H}_{3}\right)$ diperoleh bahwa kepemilikan institusional berpengaruh positif terhadap kos keagenan. Berpengaruh positif menunjukkan bahwa dengan adanya kepemilikan institusional akan dapat meningkatkan kos keagenan. Hasil ini tidak konsisten dengan penelitian Chrutcley et al., (1999) yang menyatakan bahwa dengan adanya kepemilikan institusional akan dapat menurunkan kos keagenan.Kondisi ini mungkin disebabkan karena rata-rata kepemilikan institusional dari perusahaan sampel masih rendah. Kepemilikan institusional yang besar akan mampu membantu manajemen dalam pengambilan keputusan dan dapat memonitoring kinerja manajemen dengan baik sehingga kos keagenan dapat diminimalisir. Karena nilai rata-rata dari kepemilikan institusional dalam penelitian ini masih rendah sehingga hak kontrol dari pemegang saham institusional juga rendah yang mengakibatkan kurang mendorong peningkatan monitoring yang lebih optimal terhadap kinerja manajemen.Dalam perusahaan Perseroan Terbatas (PT) hak kontrol dipegang oleh pemegang saham mayoritas dan mungkin pemegang saham mayoritas tersebut tidak lebih ahli dari pemegang saham institusional sehingga menyebabkan pengambilan keputusan yang kurang tepat. Oleh karena itu kos keagenan akan meningkat.

Hasil pengujian hipotesis keempat $\left(\mathrm{H}_{4}\right)$ diperoleh kepemilikan asing tidak berpengaruh terhadap kos keagenan. Hasil ini tidak konsisten dengan penelitian Porta et al., (1999) yang menyatakan bahwa dengan monitoring pemegang saham asing relatif lebih tinggi dapat menurunkan kos keagenan. Namun, hasil ini konsisten dengan penelitian Nugroho dan Syafruddin (2012) yang membuktikan kepemilikan asing tidak berpengaruh terhadap kos keagenan. Kondisi ini dapat terjadi karena adanya perbedaan hukum yang berlaku dan ketidaktahuan kondisi lokal dapat membuat pemegang saham asing kurang memengaruhi kos keagenan. Selain itu jumlah rata-rata kepemilikan asing dalam penelitian ini terbilang rendah sehingga belum mampu memengaruhi kondisi dan hasil kinerja.

Hasil pengujian hipotesis kelima $\left(\mathrm{H}_{5}\right)$ menunjukkan bahwa kebijakan dividen tidak berpengaruh terhadapkos keagenan. Hasil ini konsisten dengan temuan Widanaputra dan Ratnadi (2008) yang menyimpulkan bahwa kebijakan dividen tidak berpengaruh secara statistik pada kos keagenan. Hasil ini tidak konsisten dengan penelitian dari Shooley et al., (1994) dan Faizal (2004) yang memeroleh hubungan negatif antara kebijakan dividen dengan kos keagenan.

Ketidakkonsistenan hasil ini mungkin disebabkan karena mayoritas sampel perusahaan sedang mengalami pertumbuhan sehingga diperlukan banyak dana untuk membiayai investasi. Kondisi ini dapat dilihat dari nilai rata-rata yang rendah sehingga kebijakan dividen belum menjadi alat yang dapat menurunkan kos keagenan.

Uji sensitivitas memberikan hasil perbandingan dari kedua proksi yaitu proksi SGA dan asset turnover. Berdasarkan perhitungan dengan bantuan program IBM SPSS versi 22, maka hasil regresi untuk proksi asset turnover adalah sebagai berikut. 
Tabel 7. Hasil Analisis Regresi Linear Berganda

\begin{tabular}{lrrrrr}
\hline \multirow{2}{*}{ Model } & \multicolumn{2}{c}{$\begin{array}{c}\text { Unstandardized } \\
\text { Coefficients }\end{array}$} & $\begin{array}{c}\text { Standardized } \\
\text { Coefficients }\end{array}$ & \multicolumn{1}{c}{$\mathrm{t}$} & \multirow{2}{*}{ Sig. } \\
\cline { 2 - 4 } & \multicolumn{1}{c}{ B } & \multicolumn{1}{c}{ Std. Error } & \multicolumn{1}{c}{ Beta } & & \\
\hline (Constant) & 0,474 & 0,041 & & 11,486 & 0,000 \\
FCF & 0,157 & 0,137 & 0,107 & 1,148 & 0,255 \\
DAR & $-0,473$ & 0,060 & $-0,751$ & $-7,894$ & 0,000 \\
K.Ins & 0,054 & 0,058 & 0,095 & 0,921 & 0,361 \\
K.Asing & 0,192 & 0,072 & 0,275 & 2,653 & 0,010 \\
DPR & $-0,008$ & 0,064 & $-0,012$ & $-0,127$ & 0,900 \\
F Fitung $_{\text {Sig. Fhitung }}$ & & & 13,885 & & \\
R $^{2}$ & & & 0,000 & & \\
Adjusted $\mathrm{R}^{2}$ & & & 0,536 & & \\
\hline
\end{tabular}

Berdasarkan Tabel 7 dapat dibentuk persamaan regresi linear berganda sebagai berikut. AC_AT $=0,474+0,157 \mathrm{FCF}-0,473 \mathrm{DAR}+$ 0,054K.Ins + 0,192K.Asing - 0,008DPR + $\varepsilon \ldots(2)$

Tabel 7 menunjukkan $F_{\text {hitung }}$ sebesar 13,885 dengan signifikansi 0,000 yang berarti bahwa variabel independen dalam penelitian ini merupakan penjelas yang signifikan secara statis pada kos keagenan yang diproksi dengan asset turnover. Nilai Adjusted $\mathrm{R}^{2}$ yang dihasilkan adalah sebesar 0,498 menunjukkan bahwa keragaman kos keagenan dengan proksi asset turnover mampu dijelaskan sebesar 49,8 persen oleh free cash flow, leverage, kepemilikan institusional, kepemilikan asing, dan kebijakan dividen. Sisanya, yaitu sebesar 50,2 persen dijelaskan oleh variabel lain diluar penelitian.

Tabel 8. Perbandingan Hasil Uji Model Keseluruhan

\begin{tabular}{lccrr}
\hline \multirow{2}{*}{ Model } & \multicolumn{2}{c}{ SGA } & \multicolumn{3}{c}{ Asset Turnover } \\
\cline { 2 - 5 } (Constant) & $\mathrm{T}$ & \multicolumn{1}{c}{ Sig. } & $\mathrm{t}$ & \multicolumn{1}{c}{ Sig. } \\
FCF & 6,697 & 0,000 & 11,486 & 0,000 \\
DAR & 1,988 & 0,049 & 1,148 & 0,255 \\
K.Ins & $-4,060$ & 0,000 & $-7,894$ & 0,000 \\
K.Asing & 4,394 & 0,000 & 0,921 & 0,361 \\
& 0,096 & 0,924 & 2,653 & 0,010 \\
DPR & & & & 0,900 \\
\multicolumn{1}{c}{$\mathrm{R}^{2}$} & $-0,648$ & 0,519 & $-0,127$ & 0,536 \\
\multicolumn{1}{c}{ Adjusted $\mathrm{R}^{2}$} & & 0,269 & & 0,498 \\
\hline
\end{tabular}

Tabel 8 menyajikan perbandingan hasil analisis model secara keseluruhan. Berdasarkan Tabel 8 dapat diketahui bahwa kedua proksi memberikan arah t hitung yang sama namun hasil yang berbeda pada signifikansinya. Dalam proksi SGA diperoleh tiga variabel yang 
memiliki nilai signifikan ( $\mathrm{p}$ value $\leq 0,05$ ), sedangkan pada proksi asset turnover diperoleh hanya dua variabel yang memiliki nilai signifikan. Hal ini berarti proksi SGA lebih mampu membuktikan pengaruh dari variabel-variabel independen yang diteliti terhadap kos keagenan. Kedua proksi memberikan hasil yang sama padaLeverage yang artinya mengukur leverage dengan proksi yang mana saja akan tetap memberikan hasil yang sama.

Secara umum perbedaan hasil mungkin dikarenakan sampel dalam penelitian ini adalah seluruh sektor di BEI dan masing-masing sektor memiliki karakteristik yang berbeda-beda.Misalnya, pada perusahaan manufaktur memiliki jumlah aset yang besar dan penjualan yang tinggi, sedangkan dalam perusahaan jasa memiliki jumlah penjualan yang rendah dengan jumlah aset yang besar.Sehingga bercampurnya seluruh sektor mungkin dapat menyebabkan terjadinya hasil yang berbeda.

\section{PENUTUP}

Simpulan. Berdasarkan hasil analisis maka dapat disimpulkan Free cash flow berpengaruh positif terhadap kos keagenan. Hal ini menunjukkan bahwa dengan adanya peningkatan free cash flow akan menyebabkan kos keagenan juga meningkat.Leverage berpengaruh negatif terhadap kos keagenan. Penurunan kos keagenan disebabkan oleh pengawasan terhadap manajemen semakin berkurang karena si pemilik dana (debtholder)mampu memonitoring kinerja manajemen dengan baik atas dana yang dipinjamkan.Kepemilikan institusional tidak berhasil membuktikan berpengaruh negatif terhadap kos keagenan, tetapi hasil membuktikan kepemilikan institusional berpengaruh positif terhadap kos keagenan.Kepemilikan asing tidak berhasil membuktikan berpengaruh negatif terhadap kos keagenan. Kondisi ini terjadi mungkin karena adanya perbedaan hukum yang berlaku, dan ketidaktahuan kondisi lokal dapat membuat pemegang saham asing belum dapat mengurangi kos keagenan.Kebijakan dividen tidak berhasil membuktikan berpengaruh negatif terhadap kos keagenan. Kondisi ini mungkin disebabkan karena mayoritas sampel perusahaan sedang mengalami pertumbuhan.

Saran. Saran yang dapat disampaikan terkait dengan penelitian ini adalah free cash flow yang besar dalam perusahaan dapat disalahgunakan oleh manajemen sehingga kos keagenan meningkat dan untuk menurunkan kos keagenan sebaiknya mengurangi free cash flow dengan membagikan dividen kepada pemegang saham. Dan, calon investor umum akan memutuskan membeli saham perusahaan dengan kos keagenan yang rendah, salah satu hal yang dapat dilihat oleh calon investor adalah kepemilikan institusional yang besar karena dapat memengaruhi keputusan manajemen dan memonitoring kinerja manajemen dengan baik.

\section{DAFTAR RUJUKAN}

Ahmad Afridian Wirahadi dan Septriani Yossi. (2008) "Konflik Keagenan, Tinjauan Teoritis dan Cara Menguranginya". Jurnal Akuntansi dan Manajemen, (3): 47-55.

Almilia, Luciana Spica. (2008) "Faktor-faktor yang Mempengaruhi Pengungkapan Sukarela Internet Financial and Sustainability Reporting”. Jurnal Akuntansi dan Auditing Indonesia, 12 (2). 
Ang, J. S., Cole, R. A., dan Lin., J.W. (2000) “Agency Cost and Ownership Structure”. Journal of Finance 55: 377-397.

Anggraini, Ririn Dwi. (2011) "Pengaruh Kepemilikan Institusional dan Kepemilikan Asing Terhadap Pengungkapan Pertanggungjawaban Sosial Perusahaan dalam Annual Report (Studi Empiris Pada Perusahaan Non Keuangan yang Tercatat di BEI Tahun 2008-2009)". Skripsi. Fakultas UNDIP Semarang.

Aryani, Etha Rizki. (2011) "Pengaruh Good Corporate Governance dan Struktur Kepemilikan Terhadap Agency Cost”. Skripsi. Fakultas Ekonomi Universitas Diponegoro, Semarang.

Barnae, Amir dan Amir Rubin. (2005) Corporate Sosial Responsibility as a Conflict Between Shareholders. www.ssrn.com.

Bapepam-LK. (2011) Lampiran Keputusan Ketua BAPEPAM No.KEP-346/BL/2011 (Retrifed from: www.bapepam.co.id/bapepam-LK.pdf /04-01-2016).

Brealey, R.A., Myers, S.C., dan Marcus, A.J. (2008) Fundamentals of Corporate Finance.Sixth Edition. Singapore: Mc Graw-Hill.

Brigham, Eugene F. Dan Joe F Houston. (2011) Dasar-dasar Manajemen Keuangan. Salemba Empat: Jakarta.

Brush T. H., Philip B. And Margaretha H. (2000) "The Free Cash Flow Hyphothesis for Sales Growth and Firm Performance.Strategic", Management Journal, 21: 455-472.

Byrd, J. (2010) "Financial Policies and the Agency Costs of Free cash Flow: Evidence from the Oil Industry". International Review of Accounting, Banking and Finance 2(2).

Chu, Junhong. (2011) “Agency Cost under the Restriction of Free Cash Flow”. Journal of Service Science and Management 4: 79-85.

Crutchley and Hansen. (1989) A test of The Agency Theory of Managerial Ownership, Corporate Leverage, and Corporate Dividends. Financial Management/Winter 18: 36-46.

Denis, D., McConnell. (2003) "Internasional Corporate Governance". Journal of Financial and Quantitative Analysis38: 1-36.fa

Fachrudin, Khaira Amalia. (2011) "Analisis Pengaruh Struktur Modal, Ukuran Perusahaan, dan Agency Cost Terhadap Kinerja Perusahaan". Jurnal Akuntansi dan Keuangan13(1): 37-46.

Faizal. (2004) Analisis Agency Cost, Struktur Kepemilikan, dan Mekanisme Corporate Governance. Dalam Simposium Nasional Akuntansi VII Denpasar: 197-208.

Fiona Putri Hasyim. (2013) Inilah Perusahaan Tbk dengan GCG Terbaik. (Retrifed from: bisnis.tempo.co/read/news/2013/03/25/090469303/inilah-30-perusahaan-tbk-dengangcg-terbaik / 5-9-2015.

Fosberg, Richard H. Dan Sidney Rosenberg. (2003) "Agency Cost Control”. Journal of American Academy of Business Cambridge: 299

Gedajlovic, E. dan D. M. Shapiro. (2002) "Ownership and Firm Profitability in Japan". The Academy of Management Journal 45(3): 575-585

Ghozali, Imam. (2013) Aplikasi Analisis Multivariate dengan Program SPSS. Semarang: Badan Penerbit Universitas Diponegoro.

Gul, S., M. Sajid, N. Razzaq, F. Afzal. (2014) Agency Cost, Corporate Governance and Ownership Structure (The Case of Pakistan). International Journal of Business and Social Science 3(9): 268-277 
Hadiprajitno, Paulus Basuki. (2013) "Struktur Kepemilikan, Mekanisme Tata Kelola Perusahaan, dan Biaya Keagenan di Indonesia". Jurnal Akuntansi dan Auditing 9: 97-127.

Jensen, M. (1986) "Agency cost of free ash flow, corporate finance, and takeovers. American”, Economic Review 76: 323-339.

Jensen, M.C., and W.H Meckling. (1976) "Theory of the Firm: Management Behavior, Agency Cost, and Ownership Structure". Journal of Financial Economic 4: 305-360.

Jurkus, A.F., Park, Jung Chul., Woodard, Lorraine S. (2011) "Women in Top Management and Agency Cost", Journal of Business Research 64.

Kaihatu, Thomas S. (2006) "Good Corporate Governancedan Penerapannya di Indonesia". Jurnal Manajemen dan Kewirausahaan 8(1): 1-9.

Karen, F.R. (2003) A Blue Print for Corporate Governance. New York: American Management Assosiation.

Khan, Asma., Kaleem Ahmad., Nasir, Mian Sajid. (2012) "Impact of Financial Leverage on Agency Cost of Free Cash Floe: Evidence from the Manufacturing Sector of Pakistan". Journal Basic and Applied Acientific Research 2(7).

Mann, Steven V. and Neil W. Sicherman. (1991) "The Agency Costs of Free Cash Flow: Acquisition Activity and Equity Issues". Journal of Business 64: 213-227

Messier, William F., Steven M. Glover, Douglas F. Prawitt. (2006) Auditing and Assurance Services-A Systemic Approach. Jakarta: Salemba Empat.

Nugroho, A. Saputro dan Muchamad Syafruddin. (2012) Pengaruh Struktur Kepemilikan dan Mekanisme Good Corporate Governance terhadap Biaya Keagenan. Diponegoro Journal of Accounting 1(1): 1-13

Nuswandari, Cahyani. (2009) "Pengaruh Good Corporate Governance Terhadap Kinerja Perusahaan pada Perusahaan yang Terdaftar di Bursa Efek Indonesia". Jurnal Bisnis dan Ekonomi 16(2): 70-84.

Ozkan, Aydin. (2001) "Determinants of Capital Structure and Adjustment To Long Run Target: Evidence from UK Company Panel Data". Journal Business Finance and Accounting 175-198.

Piramita, Santi. (2012) Analisis Pengaruh Free Cash Flow terhadap Agency cost dan Kinerja Keuangan. Skripsi. Universitas Indonesia.

Porta, R. L., Florensio L., Shleifer Andrei, and Vishny.Robert W. (1999) Agency Problem and Dividend Policies Around the World. Working paper (Harvard University).

Purnami, Ketut. (2011) "Pengaruh Kepemilikan Manajerial, Kepemilikan Institusional, Kebijakan Dividen, dan Leverage pada Biaya Keagenan (Agency Cost)". Thesis. Universitas Udayana.

Rahmadiyani, Ni'mah. (2012) "Analisis Pengaruh Struktur Kepemilikan terhadap Agency Cost dengan Aktivitas Pengawasan Dewan Komisaris sebagai Variabel Pemoderasi”. Skripsi. Universitas Indonesia.

Richardson, Scott. (2006) “Overinvestment of Free Cash Flow”. Review Accounting Study 11: 159-189.

Schooly, Diane K. and L. Dwayne Barney Jr. (1994) "Using Dividend Policy and Managerial Ownership to Reduce Agency Cost".The Journal of Financial Research 17: 363-373. 
Simerly, R. And Li, M. (2000) "Environmental Dynamism, Capital Structure and Performance: A Theoritical Integration and An Empirical Test", Strategic Management Journal 21: 31-49.

Sugiyono. (2013) Statistika UntukPenelitian.Bandung: Alfabeta

Tarjo. (2005) "Analisa Pengaruh Free Cash Flow dan Kepemilikan Manajerial Terhadap Kebijakan Hutang pada Perusahaan Publik di Indonesia". Journal Riset Akuntansi Indonesia, 18(1): 82-10.

Wang, George Yungchih. (2010) "The Impact of Free Cash Dlow and Agency Cost on Firm Performance". Journal Service Science \& Management 3: 408-418.

Widanaputra, A.A.G.P. dan Ratnadi, Ni Made Dwi. (2008) "Pengaruh Kebijakan Dividen dan Kepemilikan Manajerial terhadap Kos Keagenan”, AUDI Jurnal Akuntansi dan Bisnis 3(2): 186-197.

Yasa, Gerianta Wirawan. (2010) Pemeringkatan Obligasi Perdana Sebagai Pemicu Manajemen Laba: Bukti Empiris Dari Pasar Modal Indonesia. Simposium Nasional Akuntansi XIII Purwokerto.

Yegon, C., J. Sang, J. Kirui. (2014) "The Impact of Corporate Governance on Agency Cost: Empirical Analysis of Quoted Services Firms in Kenya". Research Journal of Finance and Accounting, 5(12): 145-154. 